\title{
Allogeneic Cytomegalovirus-Specific Cytotoxic T lymphocytes
}

National Cancer Institute

\section{Source}

National Cancer Institute. Allogeneic Cytomegalovirus-Specific Cytotoxic T Iymphocytes.

NCl Thesaurus. Code C91095.

A population of allogeneic cytotoxic T lymphocytes (CTLS) specifically reactive to the herpes virus cytomegalovirus (CMV) with potential immunomodulating and antiviral activities. Upon immunoprophylactic adoptive cell therapy infusion with allogeneic cytomegalovirus-specific cytotoxic T lymphocytes, these CT Ls may help reconstitute CMV-specific CTL responses in CMV-infected immunocompromised hosts after allogeneic hematopoietic stem cell transplant, thereby potentially preventing the occurrence of CMV viral disease or reducing the amount of antiviral drug therapy. 